\title{
Methods of estimating reserves of productivity growth
}

\author{
Pavel Oleinik ${ }^{1}$, and Tatyana Kuzmina ${ }^{1 *}$ \\ ${ }^{1}$ Moscow State University of Civil Engineering, Yaroslavskoe shosse, 26, Moscow, 129337, Russia
}

\begin{abstract}
Two levels of the estimation of labor productivity reserves are considered: for lower-level (secondary) subdivisions and a construction enterprise. For secondary subdivisions it is recommended to implement the full-scale approach through interconnected single-factor, multifactor and predictable methods. The ground of these methods is based on correlation-regressive models of changes in natural output by types of construction and installation works. For the construction enterprise, the authors have allocated groups of factors that determine the average annual output per worker-production of contract works, their structure, production assets and circulating assets, labor, prime cost and operational management. The foregoing provisions are illustrated by examples based on a large body of statistical information from construction practice.
\end{abstract}

\section{Introduction}

Management of productivity growth reserves is the major direction of improving the efficiency of building production. Therefore, the formation and adjustment of the brigades are carefully worked out in preparation for construction production in most construction companies and are provided through the following arrangements [1, 2]:

- definition of the structure of specialized workflows. At the same time, the specialized workflow is led by one lower subdivision - a complex and specialized brigade (a mechanized complex, a complex or specialized section, a section of workflow). The lower subdivision, assigned to the specialized work flow, completes the corresponding type of work in the zone and performs handing over the work to subsequent subdivision by sections (divisions) within one or several steps of workflow;

- division of production into component parts, i.e. each object in the longitudinal (transverse) axes is divided into zones (sections) of work, the number and size of which is determined depending on the features of the organization of the technological process at the objects under construction, the volume and technology of production of building and construction works. The zones of the object of work are conducted in parallel;

- calculation of workflow volume according with accepted division in the term of zones, areas and specialized streams;

\footnotetext{
Corresponding author: KuzminaTK@mgsu.ru
} 
- establishment of the priority of works per work area, taking into account the technological sequence of works by specialized workflows;

- workload volume distribution between contractors, coordination of their work regimes (establishment of shift schedule for each work area and specialized workflow), definition of manpower and duration of work, determination of the quantitative composition of workers;

- performance of calculations of parameters of all specialized workflows - time of beginning and completion of work at each division, number of workers and construction machines requirements, supplies of construction materials, products and structures.

This sequence and content of the stages of the arrangements make it possible to take into account a complex of influencing organizational and technological factors when selecting stable brigade composition and create favorable conditions for the continuous and uniform load of lower divisions throughout the whole period of work process at the objects.

\section{Methodology}

Complex and specialized brigades are two main forms of organization of work applied in construction. In complex brigades, as a rule, the loss of working time is minimized at the joints between adjacent works, building machines and mechanisms are rationally used. The number of workers in such brigades is determined from the ratio of the normative manpower to the planned percentage of the fulfillment of the norms and the duration of the work, and the qualification composition of staff is determined in accordance with the calculation of labor and wages [7]. The approximate composition of a complex brigade for the construction of brick apartment houses, as a rule, can be used in such a composition (3-shift brigade, No of units): 8 masons (3rd - 5th grade, 3rd - 4th grade, 2nd - 3rd grade), 8 riggers (3rd - 5th grade, 3rd - 4th grade, 2nd - 3rd grade), 3 scaffolders (4th grade), 7 carpenters (2nd - 5th grade, 3rd - 4th grade, 2 nd - 3rd grade), 3 tower crane machinists (5th grade), 2 electric welders (5th grade), 2 electricians (4th grade), 2 motor mechanics ( $3 \mathrm{rd}$ grade), 5 mechanics ( 3 rd - 4th grade, 2 nd - 3rd grade). Total number is 40 workers.

The formation of specialized brigades is carried out to perform homogeneous work and includes workers of the same profession - concrete workers, masons, finishers, etc. Productivity growth in such brigades is $8-12 \%$ higher than in complex brigades.

In the process of calculating the staff number in brigades, the range of changes in the number of workers is estimated through the variance $\sigma_{\mathrm{x}}^{2}$ and the standard deviation $\sigma_{\mathrm{x}}$ :

$$
\begin{gathered}
\sigma_{x}^{2}=\left(\sum|x-\bar{x}|^{2}\right) / n \\
\sigma_{x}=\sqrt{\sum|x-\bar{x}|^{2 / n}}
\end{gathered}
$$

where $\mathrm{x}$ is the number of workers per section; $\overline{\mathrm{x}}$ is average number of workers per section; $\mathrm{n}$ is number of section of works.

$\mu_{\sigma} / \mu_{\mathrm{x}}$ ratio is used to verify the correctness of the decision on the number of brigade staff where:

$$
\begin{aligned}
& \mu_{x}=\left(\sum|x-\bar{x}|\right) /(n \sqrt{n}) \\
& M_{\sigma}=\sigma_{x} / \sqrt{u}
\end{aligned}
$$

If the ratio $\mu_{\sigma} / \mu_{x}$ is within $1.25-1.30$, random errors are followed the law of normal distribution. 
An example of estimating of the deviation of the number of workers with reference to mounting work at production purpose objects is presented in Table 1.

Table 1. Calculation of variance and standard deviation number of workers in the sections of the production complex

\begin{tabular}{|c|c|c|c|c|c|c|c|c|}
\hline \multirow[t]{2}{*}{ Operations } & \multirow[t]{2}{*}{ Action by } & \multicolumn{3}{|c|}{$\begin{array}{l}\text { Number of } \\
\text { workers per } \\
\text { section }(x)\end{array}$} & \multirow{2}{*}{$\begin{array}{c}\text { Average } \\
\text { number } \\
\text { of } \\
\text { workers } \\
\bar{x}\end{array}$} & \multirow{2}{*}{$\begin{array}{c}\text { Vari- } \\
\text { ence } \\
\sigma_{\mathrm{x}}^{2}\end{array}$} & \multirow{2}{*}{$\begin{array}{c}\text { Standard } \\
\text { deviation } \\
\sigma_{\mathrm{x}}\end{array}$} & \multirow{2}{*}{$\frac{\mu_{\sigma}}{\mu_{\mathrm{x}}}$} \\
\hline & & 2 & 3 & 4 & & & & \\
\hline 1 & 2 & 3 & 4 & 5 & 6 & 7 & 8 & 9 \\
\hline \multicolumn{9}{|c|}{ Assembling of frame } \\
\hline $\begin{array}{l}\text { Installation } \\
\text { of rein- } \\
\text { forced } \\
\text { concrete } \\
\text { partitions }\end{array}$ & Assemblers & 6 & 4 & 5 & 5 & 1.67 & 1.291 & 1.29 \\
\hline $\begin{array}{l}\text { Mounting of } \\
\text { floor slabs }\end{array}$ & Assemblers & 4 & 6 & 2 & 4 & 2.67 & 1.633 & 1.22 \\
\hline $\begin{array}{l}\text { Installation } \\
\text { of rein- } \\
\text { forced con- } \\
\text { crete } \\
\text { panels }\end{array}$ & Assemblers & 3 & 10 & 2 & 5 & 9.67 & 3.109 & 1.04 \\
\hline $\begin{array}{r}\text { Total number } \\
\text { in assembl }\end{array}$ & $\begin{array}{l}\text { of assemblers } \\
\text { ng brigade }\end{array}$ & 10 & 20 & 9 & 14 & 34.00 & 5.831 & 1.09 \\
\hline \multicolumn{9}{|c|}{ Installation of enclosing structures } \\
\hline $\begin{array}{l}\text { Brick } \\
\text { masonry of } \\
\text { partitions } \\
\text { and walls } \\
\text { with sealed } \\
\text { joints and } \\
\text { seam } \\
\text { jointing }\end{array}$ & Masons & 13 & 14 & 6 & 7 & 25.75 & 5.268 & 1.11 \\
\hline $\begin{array}{l}\text { Installation } \\
\text { of plastic } \\
\text { and profiled } \\
\text { glass parti- } \\
\text { tions }\end{array}$ & Masons & 15 & 13 & 13 & 14 & 1.00 & 1.000 & 1.00 \\
\hline \multicolumn{2}{|c|}{$\begin{array}{c}\text { Total number of masons in } \\
\text { mason brigade }\end{array}$} & 28 & 27 & 19 & 21 & 121.00 & 11.000 & 1.29 \\
\hline
\end{tabular}

Rationally selected team of brigades immediately affects the work efficiency. However, the level of reserves of productivity growth is constantly changing depending on the implementation of scientific and technical achievements. The range of such reserves is large enough and varies from reducing intra-shift downtime to increasing advanced technologies volume and production work methods. So, there is a need to continuously determine the level of labour performance and appropriate corrective actions [3, 4, 5]. 


\section{Main part}

The most appropriate indicator of labor productivity is the natural work output, since it adequately reflects the conditions for the production of work. It is known that the reserves planned for implementation are only one part of them. The aggregate of the actually achieved (basic) level of work output and the planned increase in work output due to the reserves planned for implementation reflects the projected work output. The difference between the forecast work output and the factually achieved (base) is the increase in work output due to the implementation of reserves for the planned period.

Thus, in order to forecast natural work output, its continuous planning, quantitative evaluation of planned decisions, it is necessary to know the actually reached level of work output and the absolute amount of reserves in the context of the main factors affecting the growth of work output. In fact, the achieved level of development and basic work output should be considered definite, since in most construction organizations of the country this indicator is calculated monthly and is accumulated according to special computer programs in the context of brigades, offices and trusts $[6,7,8]$.

Analysis of indicators of natural work output by type of work in various construction and installation organizations shows that the achieved level is formed under the influence of a wide range of interrelated factors. These factors include, in particular, the amount of construction and construction work, number of workers, daytime and shift downtimes, time spent on non-productive work, proportion of manual labor, availability of unskilled force employment, level of specialization and resource concentration, losses due to disease, wage payment systems, etc.

Naturally, in order to conduct a deep analysis of the achieved level of development and calculate its growth to an absolute value, it is necessary to know the degree of influence of the above mentioned factors on the formation of the work output and the range of their variation $[9,10,11]$.

In this regard, the following interrelated methods for estimating the level of labor productivity can be distinguished:

- one-factor method, which is to determine the level of natural extraction at the time until the end of the base period;

- multifactor method, which allows estimating the level of natural production for the whole base period;

- a predictable method that provides a definition of the level of productivity of labor in the post-baseline period.

The first method establishes the trend of changes in natural output. In the production of construction and installation works, the output per shift of one worker, depending on the conditions of production, can vary significantly, for example, for concrete works from 0.9 to $2.4 \mathrm{~m} 3$, for installation works from 1.5 to $3.5 \mathrm{~m} 3$, etc. Therefore, at this stage, we should use correlation-regressive models, some of which are listed in Table. 2. In the vast majority of such models, the correlation coefficients are in the range of $0.6-0.9$.

Table 2. Natural output change model (examples)

\begin{tabular}{|l|c|c|c|}
\hline $\begin{array}{c}\text { Nomenclature of building } \\
\text { and installation works }\end{array}$ & $\begin{array}{c}\text { Period of time } \\
\text { (quarter) }\end{array}$ & Equation & $\begin{array}{c}\text { Correlation } \\
\text { coefficient }\end{array}$ \\
\hline \multirow{2}{*}{ Concrete } & I - II & $\mathrm{B}=6.64-4.93 \mathrm{x}$ & 0.983 \\
& II - III & $\mathrm{B}=0.09+1.02 \mathrm{x}$ & 0.883 \\
\hline \multirow{2}{*}{ Installation works } & I - II & $\mathrm{B}=1.32+0.44 \mathrm{x}$ & 0.712 \\
& II - III & $\mathrm{B}=-9.67+7.21 \mathrm{x}$ & 0.881 \\
\hline \multirow{2}{*}{ Masonry } & I - II & $\mathrm{B}=7.63-7.94 \mathrm{x}$ & 0.749 \\
& II - III & $\mathrm{B}=-0.69+1.98 \mathrm{x}$ & 0.793 \\
\hline
\end{tabular}


The second method provides the construction of a model of the change in labor productivity, taking into account the influence of the entire set of factors, the statistics of which was collected for the entire base period. For example, the analysis of the initial data on installation works showed that the main factors affecting the index of natural production (B) are:

- volume of work (x);

- number of workers involved directly in the production process $\left(\mathrm{x}_{1)}\right.$;

- coefficient of downtime $\left(\mathrm{x}_{2}\right)$;

- factor of unproductive expenses $\left(\mathrm{x}_{3}\right)$;

- specific weight of manual labor $\left(\mathrm{x}_{4}\right)$;

- specific weight of the volume of work performed by unskilled labor force $\left(\mathrm{x}_{5}\right)$.

The characteristics of the main parameters of the initial data are given in Table. 3. In this case, we excluded less significant factors, in which the coefficients of pair correlation in absolute value turned out to be sufficiently small.

Table 3. Basic parameters of the initial data (installation works)

\begin{tabular}{|c|c|c|}
\hline Factor code & $\begin{array}{c}\text { Mathematical } \\
\text { expectation }\end{array}$ & Standard deviation \\
\hline $\mathrm{B}$ & 2.7034 & 0.6106 \\
\hline $\mathrm{B}_{1}$ & 8054.1406 & 2979.0588 \\
\hline $\mathrm{B}_{2}$ & 47.8906 & 15.0819 \\
\hline $\mathrm{B}_{3}$ & 0.0828 & 0.0253 \\
\hline $\mathrm{B}_{4}$ & 0.3603 & 1.9867 \\
\hline $\mathrm{B}_{5}$ & 0.2692 & 0.0507 \\
\hline $\mathrm{B}_{6}$ & 0.1348 & 0.1425 \\
\hline
\end{tabular}

The values of correlation coefficients of dependent factors are summarized in Table. 4.

Table 4. Coefficients of correlation of dependent factors (installation works)

\begin{tabular}{|c|c|c|c|c|c|c|c|}
\hline $\begin{array}{c}\text { Factor } \\
\text { code }\end{array}$ & $\mathbf{B}$ & $\mathbf{B}_{\mathbf{1}}$ & $\mathbf{B}_{\mathbf{2}}$ & $\mathbf{B}_{\mathbf{3}}$ & $\mathbf{B}_{\mathbf{4}}$ & $\mathbf{B}_{\mathbf{5}}$ & $\mathbf{B}_{\mathbf{6}}$ \\
\hline $\mathrm{B}$ & 1 & 0.3905 & -0.1684 & 0.0076 & -0.0702 & -0.1701 & -0.1798 \\
\hline $\mathrm{B}_{1}$ & - & 1 & 0.6855 & 0.0799 & 0.0589 & 0.2253 & -0.1415 \\
\hline $\mathrm{B}_{2}$ & - & - & 1 & 0.0191 & 0.0778 & 0.3402 & -0.0281 \\
\hline $\mathrm{B}_{3}$ & - & - & - & 1 & -0.1643 & 0.1170 & -0.1373 \\
\hline $\mathrm{B}_{4}$ & - & - & - & - & 1 & 0.1025 & 0.1483 \\
\hline $\mathrm{B}_{5}$ & - & - & - & - & - & 1 & 0.3379 \\
\hline $\mathrm{B}_{6}$ & - & - & - & - & - & - & 1 \\
\hline
\end{tabular}

As a result, the model of natural production for installation works is the following:

$$
B=2.42+3.1 \cdot 10^{-4} \cdot x-3.18 \cdot 10^{-2} \cdot x_{1}-1.38 \cdot x_{2}-1.84 \cdot 10^{-2} \cdot x_{3}-1.12 \cdot x_{4}-1.48 \cdot 10^{-1} \cdot x_{5}
$$

Where: $B$ is the index of natural output per worker per shift, $\mathrm{m} 3$.

From the equation of the model it follows that the natural output depends directly on the amount of work and inversely proportional to the number of workers participating directly in the production process, the magnitude of intra-shift downtime and unproductive expenditures, proportion of manual labor and proportion of the amount of work performed by unskilled manpower. 
The third method is necessary to fulfill the forecast of natural output according to the information of the base period. However, using the model obtained earlier provides relevant tolerances in effect regulation influencing on factors depending on the goal of management of productivity growth reserve.

Thus, the evaluation of labor productivity in the lower construction subdivisions, based on indicators of natural output, is objective and sufficiently accurate. Certainly, the possibility of using such natural methods is due to the homogeneity of construction products.

At the same time, for the construction enterprise, which finished construction products are multi-nomenclature, labor productivity reserves are estimated by cost indicators. On the basis of many years of practice, such companies have established basic factors that determine the changes of the average annual output per worker (Table 5). As a rule, these factors represent such spheres as production of contract works, composition building and construction works, production assets and current assets, labor, production costs and operational management. For example, for construction companies (general construction trust type), the model of the output for one worker will have the following form:

$$
C=1.21 \cdot 10^{6}+0.39 \cdot Y_{1}+1.34 \cdot Y_{2}-7.16 \cdot 10^{2} \cdot Y_{3}-1.22 \cdot 10^{2} \cdot Y_{4}
$$

where $\mathrm{C}$ is average annual output per worker, in Russian rubles (RUB);

$Y_{1}, Y_{2}, Y_{3}, Y_{4}$ - are the corresponding indicators of force-account work volume, average wage, staff turnover level and labor intensity coefficient.

Table 5. Groups of factors affecting the average annual output per worker

\begin{tabular}{|c|l|l|}
\hline No & \multicolumn{1}{|c|}{$\begin{array}{c}\text { Group of } \\
\text { influencing factors }\end{array}$} & \multicolumn{1}{c|}{ Main influencing factors } \\
\hline 1 & $\begin{array}{l}\text { Production of contract } \\
\text { works }\end{array}$ & $\begin{array}{l}\text { Volume of building and construction works; } \\
\text { amount of force-account work; } \\
\text { scope of contracting organizations works; } \\
\text { level of industrial and technological specialization. }\end{array}$ \\
\hline 2 & $\begin{array}{l}\text { Composition of building } \\
\text { and construction works }\end{array}$ & $\begin{array}{l}\text { Volume by type of construction, building and } \\
\text { special construction works; } \\
\text { volume of loading / unloading and storage } \\
\text { operations; } \\
\text { level of completion of structures, products and } \\
\text { equipment. }\end{array}$ \\
\hline 3 & $\begin{array}{l}\text { Production assets and } \\
\text { current assets }\end{array}$ & $\begin{array}{l}\text { Capacity of fixed assets; } \\
\text { normative current assets; } \\
\text { costs for the operation of construction machinery } \\
\text { and mechanisms; } \\
\text { costs for the operation of vehicles; } \\
\text { costs for the manufacture and operation of tools. }\end{array}$ \\
\hline 5 & Labor & $\begin{array}{l}\text { Number of employees and certain categories of } \\
\text { employees; } \\
\text { wage fund; } \\
\text { coefficients of labor intensity; } \\
\text { level of staff turnover; } \\
\text { proportion of employees in subsidiary industries; } \\
\text { power-to-weight ratio of labor. }\end{array}$ \\
\hline 5 & $\begin{array}{l}\text { Material intensity of production; } \\
\text { level of overheads. }\end{array}$ \\
\hline & Cost of production &
\end{tabular}


It should be marked that minor factors were excluded in the process of calculation. Moreover, during the industrialization of construction, many operations for the processing of materials, the manufacture of parts and semi-finished products are transferred from construction sites to enterprises. Reducing the composition of operations performed on construction sites, causes a corresponding reduction of the coefficient of labor-intensiveness of building and construction works and the growth of output in these works $[1,12,13]$. Consequently, output is inversely proportional to the coefficient of labor intensity of building and construction works.

In the labor plans of construction enterprises, certain proportions are established between the growth rates of labor productivity and the average wage, on appropriate calculation basis $[14,15]$. In this case, the anticipated growth of labor productivity in comparison with the growth of the average wage is envisaged, which determines the reduction of the cost of building and construction works and the increase of the profitability of construction production. With the growth in output, the average wage increases, and therefore the dependence of the average output on the average wage is directly proportional.

The elimination of staff turnover is of great importance for the output growth. In spite of some decrease in the turnover of workers in construction, this indicator in a number of building and construction enterprises is still high. The level of qualification of workers who come to work instead of those who quit is generally 1-2 classes lower. This circumstance reduces the annual output of the corresponding part of the workers by $1.5-3 \%$. Consequently, the output is inversely proportional to the turnover level.

\section{Conclusions}

In practice, two approaches are used in the activity of construction companies to manage the reserves of productivity growth, - natural (full-scale) and value. At the same time, the full-scale approach is effective for assessing the productivity of the work of lower subdivisions, and the cost approach for the enterprise as a whole.

When applying the full-scale approach, it is advisable to use three interrelated methods for estimating the level of worker productivity in natural indicators (one-factor, multifactor, and predictable). The basis of these methods is based on correlation-regressive models of the change in natural output by types of construction and installation works.

When planning and managing the labor productivity reserves of a construction enterprise, the average annual output per worker is determined, taking into account the influence of a combination of factors grouped into such areas as the production of contract works, their composition, production assets and working capital, labor, production costs and operational management.

\section{References}

1. P.P. Oleinik, V.I. Brodsky, Technology and organization of construction production, 1(2), 27-31 (2013)

2. T. Kuzmina and N. Cherednichenko, MATEC Web Conf., 86, 05012 (2016)

3. B.M. Genkin, L.G. Simkina and others, Production efficiency and the quality of life: collection of scientific papers (Federal Education Agency St. Petersburg, 286 2006)

4. P.N. Ivarovsky, Technical regulation, payments and incentives in construction: handbook (Brest, Brest State Technical University, 139 2009)

5. P.P. Oleinik, Natural and technical sciences, 10, 412-414 (2015)

6. F.I. Beskier, Formation of the system of management of construction holding ( $\mathrm{PhD}$ in Economics dissertation thesis, St. Petersburg, 2004) 
7. K.A. Kuzmin, E.N. Kucherova, Economics and entrepreneurship, 6 (71), 387-394 (2016)

8. P.P. Oleinik, T. Kuzmina, V. Zenov, MATEC Web Conf., 86, 05019 (2016)

9. L.V. Kievsky, Organizing: from construction process - to investment processes in construction. In edition: Urban development, scientific papers 2006-2014 ed. By L.V. Kievsky (Moscow, 205-221, 2014)

10. Clifford F. Gray, Erik W. Larson, Project management: a practical guide. Translation from English (Moscow, Business and Service Publishing house, 2003)

11. B.F. Shirshikov, A.M. Slavin, Civil and industrial engineering, 8, 92-95 (2016)

12. Frame J. Davidson, The New Project Management: tools for an age of rapid change, complexity, and other business realities (San Francisco: Jossey-bass, A Wiley Company, 360, 2002)

13. J.C. Jonsons, J.C. New York: MacMillan, 325 (2007)

14. Charvat Jason, Project Management Methodologies-Selecting, Implementing, and Supporting Methodologies and Processes for Projects (New Jersey, John Wiley \& Sons inc., 264, 2003)

15. L.V. Kievskiy, I.L. Kievskiy, International Journal of Applied Engineering Research, 11(1), 304-311 (2016) 